\title{
Role of Intravenous Dexmedetomidine as an Adjuvant in Labour Analgesia in Pre-eclampsia: A Prospective Study
}

\author{
Jyothsna $\mathrm{C}^{1}$, Roopa Kotha ${ }^{1}$ \\ ${ }^{1}$ Assistant Professor, Department of Anaesthesia, Maheshwara Medical College, Patancheru, Telangana, India.
}

\section{Abstract}

Background: Dexmedetomidine is a highly selective $\alpha-2$ adrenergic receptor agonist with several diverse actions like sedation, anxiolysis, sympatholysis, analgesia, and decreased intraoperative anesthetic requirements (narcotic, inhalational). Intravenous (IV) dexmedetomidine can be used as an adjuvant in labour analgesia in preeclampsia patients as onset is faster and duration of analgesia is longer. Aim of the study: The aim of the study was to determine the role of intravenous Dexmedetomidine as an adjuvant in Labour analgesia in PIH. Subjects and Methods: This was a prospective study and was done in the department of Anaesthesia at Maheshwara Medical College. Our study included 60 full term pregnant women with preeclampsia, within 25 to 45 years age range. They were divided into two groups, as Test group and Control group of 30 patients each. Test group received IV Dexmedetomidine and Control group received IV Fentanyl. Results: Maximum number of cases 15/30 (50\%) were in the age group 31-35 years, Majority were primigravida ie, 60\% ( $36 / 60)$. Onset of analgesia was faster, duration of analgesia was longer and uterine contraction was greater with IV Dexmedetomidine as compared to IV fentanyl. Conclusion: From the present study we conclude that IV Dexmedetomidine can be used for labour analgesia in pregnant women with preecampsia and observed that onset and duration of analgesia are better and also it gives stable maternal parameters of maternal heart rate and mean blood pressure.

Keywords: Dexmedetomidine, Fentanyl, Labour analgesia, PIH, Pre-eclampsia.

Corresponding Author: Dr. Roopa Kotha, Assistant Professor, Department of Anaesthesia, Maheshwara Medical College, Patancheru, Telangana, India.

Email: roopakotha123@gmail.com

Received: February 2020

Accepted: February 2020

\section{Introduction}

Dexmedetomidine (DEX) a second generation alpha 2 adrenergic receptor specific, pharmacologically active disomer of medetomidine was first synthesized in late 1980's. DEX appears to mimic many of the actions of mythical 'ideal' sedative/analgesic agent with its wide spectrum of actions encompassing the entire peri-operative period, also has applications in the critical care services. The food and drug administration (FDA) approved the use of DEX as an ICU sedative in 1999 and its use for nonintubated patients adult and pediatric, requiring sedation prior to and/or during surgical and other procedures in 2008. ${ }^{[1]}$

DEX became the $\alpha 2$ agonist of choice, due to its greatest $\alpha 2$ : $\alpha 1$ affinity which is eight times greater than clonidine. ${ }^{[2,3]}$ This increased selectivity results in more predictable and effective sedation and analgesia and has fewer side effects. ${ }^{[4]}$ DEX has evolved as a panacea for various applications / procedures with multiple promising delivery routes. ${ }^{[2,5-8]}$

The spinal level of antinociceptive action seems to be through the substantia gelatinosa (Lamina II of Rexed in grey matter of spinal cord). It closes the gate at the dorsal horn to stimuli coming from peripheral $\mathrm{A} \delta$ and $\mathrm{C}$ fibers and also inhibits release of nociceptive humoral transmitters like substance P. It produces hyper polarization of cell membrane. These mechanisms effectively suppress, both neuronal firing, as well as, release of neurotransmitter noradrenaline at the nerve terminals. ${ }^{[9]}$ This antinociceptive effect may explain the prolongation of the sensory block when added to spinal anesthetics.

Dosage and administration of intravenous infusion of DEX is commonly initiated with a $1 \mu \mathrm{g} / \mathrm{kg}$ loading dose, administered over $10 \mathrm{~min}$, followed by a maintenance infusion of $0.2-1.0 \mu \mathrm{g} / \mathrm{kg} / \mathrm{h}$. Limiting its usefulness is the caution that the drug cannot be given as a bolus due to concerns about peripheral alpha-2B receptor stimulation with resulting hypertension.

Dexmedetomidine is a highly selective $\alpha-2$ adrenergic receptor agonist with several diverse actions like sedation, anxiolysis, sympatholysis, analgesia, and decreased intraoperative anesthetic requirements (narcotic, inhalational), cardiovascular stability, smooth recovery when used as an adjunct to general anesthesia, and also preserves respiratory function well. It was approved by United States Food and Drug Administration (US FDA) in 1999 for use in humans for short term sedation and analgesia in Intensive Care Unit (ICU) for less than 24 hours. ${ }^{[10,11]}$

Using sedatives and narcotics in a parturient have always been controversial as these drugs tend to cross the 
uteroplacental barrier and can have deleterious effects on the baby. But newer drugs like remifentanil and dexmedetomidine due to their different and unique pharmacokinetics do not cross placenta significantly. Dexmedetomidine has a high placental retention $(0.77$ maternal/fetal index). Also, it is highly lipophilic as a result of which it is retained in placental tissue. ${ }^{[12,13]}$ Because of these properties, it doesn't cross the uteroplacental barrier, and even if it does cross, it is negligible. Also, it increases the frequency and amplitude of uterine contraction directly. But one must be able to justify the use of dexmedetomidine in a parturient, as it is still an off -label use; if used for labor analgesia or as an adjunct to general anesthesia for cesarean section.

Aim of the study

The aim of the study was to determine the role of intravenous Dexmedetomidine as an adjuvant in labour analgesia in preeclampsia.

\section{Subjects and Methods}

Permission was taken from the Institutional Ethics Committee.

Informed consent was taken from all patients included in the study.

This was a prospective study done in the department of Anaesthesia at Maheshwara Medical College, Patancheru, Telanagana. The study period was of two years duration, from July 2017 to June 2019.

The present study included 60 full term pregnant women between age 25 to 45 years with history of pre-eclampsia.

The patients were selected randomly and divided into two groups; Test group and Control group. Each Group had 30 individuals.

\section{Inclusion criteria:}

Age 25 to 45 years

Full term pregnancy

Women having Preeclampsia / PIH(Pregnancy induced hypertension)

\section{Exclusion criteria:}

Age more than 45 years

Pregnant women with any other medical illness other than pregnancy induced hypertension

Allergy to dexmedetomidine

A thorough clinical history was noted including the maternal age, parity, body weight, gestational age, and history of pregnancy induced hypertension.

Complete local examination and systemic examination was done.

Routine investigations were done including complete blood picture (CBP), complete urine analysis (CUE), liver function tests (LFT), renal function tests (RFT), Random bloof glucose, Blood Group, etc.

The Test Group received intravenous dexmedetomidine 1 $\mathrm{ug} / \mathrm{kg}$ loading dose over 10-15 minutes followed by an infusion at $0.2-0.7 \mathrm{ug} / \mathrm{kg} / \mathrm{hour}$ ) at the start of active labour with Cervical dilatation of $3 \mathrm{~cm}$ and the Control Group received intravenous Fentanyl $1 \mathrm{ug} / \mathrm{kg}$ and both the drugs were stopped after delivery.
After the neonate and placenta were delivered, an infusion of 10 IU oxytocin in $500 \mathrm{ml}$ Ringer lactate solution was administered.

All the patients were monitored for blood pressure measurement and pulse oximetry. Changes in maternal heart rate, mean blood pressure and foetal heart sounds were recorded every 15 minutes after the start of the intravenous infusion. The time from start of the intravenous infusion to delivery was also noted. The uterine contraction after placental delivery was assessed by the obstetrician and scored from 0 to 3 according to the Visual Analogue Scale (VAS). Score of 0 means complete uterine relaxation and 3 means best contraction. Apgar score of the neonates was assessed by the paediatrician at 1 minute and 5 minutes, also all neonates were observed for respiratory depression and bradycardia during the first hour after delivery.

Amount of blood loss during post partum was recorded.

Any drug reactions also were noted such as itching, nausea, vomiting and hypotension.

\section{Results}

Table 1: Age-wise distribution of the cases in Test and Control Groups

\begin{tabular}{|l|l|l|}
\hline Age in years & $\begin{array}{l}\text { No. of cases } \\
\text { (Test Group) }\end{array}$ & $\begin{array}{l}\text { No. of cases } \\
\text { (Control Group) }\end{array}$ \\
\hline $25-30$ years & $07(23.3 \%)$ & $04(13.3 \%)$ \\
\hline $31-35$ years & $15(50 \%)$ & $18(60 \%)$ \\
\hline $36-40$ years & $06(20 \%)$ & $06(20 \%)$ \\
\hline $41-45$ years & $02(6.6 \%)$ & $02(6.6 \%)$ \\
\hline Total & $30(100 \%)$ & $30(100 \%)$ \\
\hline
\end{tabular}

A $\mathrm{p}$ value of less than 0.05 was considered statistically significant.

Test group: The mean age of Test Group was 32.4 years and the standard deviation was $+/-5.6$ years.

Control group: The mean age of Control Group was 33.8 years and the standard deviation was $+/-5.2$ years.

The $\mathrm{p}$ value was 0.3198 and statistically not significant.

Table 2: State of parity in Test and Control groups

\begin{tabular}{|l|l|l|l|l|}
\hline $\begin{array}{l}\text { Age (in } \\
\text { years) }\end{array}$ & Test groups & $\begin{array}{l}\text { Control } \\
\text { group }\end{array}$ & Total & P value \\
\hline $\begin{array}{l}\text { Primi } \\
\text { gravida }\end{array}$ & $16(53.3 \%)$ & $18(60 \%)$ & 34 & 0.6036 \\
\hline Multigravida & $14(46.6 \%)$ & $12(40 \%)$ & 26 & 0.6090 \\
\hline Total & 30 & 30 & 60 & - \\
\hline
\end{tabular}

Table 3: Showing actions of IV Dexmedetomidine and Fentanyl

\begin{tabular}{|l|l|l|l|}
\hline Parameters & Test group & Control group & P value \\
\hline $\begin{array}{l}\text { Mean } \\
\text { arterial } \\
\text { pressure }\end{array}$ & $78+/-6 \mathrm{mmHg}$ & $80+/-1 \mathrm{mmHg}$ & $\begin{array}{l}>0.05 \text { Not } \\
\text { significant }\end{array}$ \\
\hline Heart rate & $101+/-5.6$ & $113+/-6.2$ & $<0.05$ Significant \\
\hline $\begin{array}{l}\text { Onset of } \\
\text { analgesia } \\
\text { (seconds) }\end{array}$ & $57.3+/-10.2$ & $72.7+/-9.8$ & $<0.05$ Significant \\
\hline $\begin{array}{l}\text { Maximum } \\
\text { analgesia } \\
\text { (seconds) }\end{array}$ & $248+/-10.6$ & $152+/-12.5$ & $<0.05$ Significant \\
\hline $\begin{array}{l}\text { Duration of } \\
\text { analgesia } \\
\text { (minutes) }\end{array}$ & $162+/-54$ & $138+/-51$ & $<0.05$ Significant \\
\hline Neonate & $\begin{array}{l}\text { No difference in } \\
\text { Apgar scores }\end{array}$ & $\begin{array}{l}\text { No difference in } \\
\text { Apgar scores }\end{array}$ & Not significant \\
\hline
\end{tabular}


In the present study, no statistically significant difference was seen in the parity of the Test and Control Groups. (p value was greater than 0.05$)$. [Table 2]

The mean arterial pressure was similar in both groups but the Test Group showed consistently lower MAP values.

\section{Table 4: Showing pain during contractions}

\begin{tabular}{|l|l|l|l|}
\hline VAS & Test group & Control group & Total \\
\hline 0 & $3(10 \%)$ & $18(60 \%)$ & 21 \\
\hline 1 & $8(26.6 \%)$ & $8(26.6 \%)$ & 16 \\
\hline 2 & $17(56.6 \%)$ & $4(13.3 \%)$ & 21 \\
\hline 3 & $2(6.6 \%)$ & 0 & 2 \\
\hline Total & 30 & 30 & 60 \\
\hline
\end{tabular}

*Visual Analogue score

$P$ value was $<0.05$ and was statistically significant

Table 5: Showing Apgar score

\begin{tabular}{|l|l|l|l|}
\hline APGAR scores & Test group & Control group & Significant \\
\hline APGAR 1 min & 7.8 & 8.1 & Not significant \\
\hline APGAR 5 min & 8.3 & 8.5 & Not significant \\
\hline
\end{tabular}

\section{Discussion}

Present study compared the effects of both intravenous dexmedetomidine and intravenous fentanyl in test and control groups. All the vital signs were noted and compared with other studies.

Mishra et al, ${ }^{[14]}$ concluded that the group of patients who received Dexmedetomidine were more haemodynamically stable during labour and delivery; there was significant pain relief, shorter duration of labour and better neonatal outcome in comparison to the control group. Our findings are similar to the above study.

Palanisamy et al, ${ }^{[15]}$ reported the successful use of continuous-infusion dexmedetomidine as analgesic adjunct in intravenous patient controlled analgesia (PCA) with fentanyl for labor in a patient with occult spina bifida.

Villa, ${ }^{[16]}$ published two case reports in Rev Colomb Anaesthesiol, 2012 where dexmedetomidine was used as an adjunct for labour analgesia along with remifentanil. Both patients underwent vaginal delivery, although the first patient had instrumentation. Babies were delivered with normal Apgar scores at 1 and 5 minutes. They also reported 2 cases wherein, in one case twelve hours into the postpartum period, the mother reported not having felt pain during the expulsion phase and excellent satisfaction with the analgesic method. In the second case the quality of analgesia improved in both patients following a continuous infusion of dexmedetomidine leading to sympatholysis and superficial sedation that enabled an adequate interaction with their environment, with no evident clinical side effects that might have impaired their hemodynamic condition or the fetal status. Moreover, they both reported satisfaction with the analgesic technique.

Sia et ${ }^{a l},{ }^{[17]}$ in their editorial in International Journal of Obstetric Anaesthesia, mentioned that dexmedetomidine if used in a properly, in selected parturient can provide sedation and haemodynamic stability with minimal risk of respiratory depression.

Waleed Abdalla et al, ${ }^{[18]}$ study showed that patients receiving a combination of PCA remifentanil and dexmedetomidine
(DMET) had a lower pain score compared with remifentanil alone in the second stage of labor. DMET has an opioid sparing effect; a combination of DMET and remifentanil produces a synergistic effect that results in lower analgesic requirements and less maternal and neonatal adverse events.

\section{Conclusion}

In the present study we conclude that IV Dexmedetomidine can be used for labour analgesia in pregnant women with pre-eclampsia and observed that onset of analgesia is faster and duration of analgesia is longer. It also provides stable maternal hemodynamic parameters.

\section{References}

1. Shukry M, Miller JA. Update on dexmedetomidine: Use in nonintubated patients requiring sedation for surgical procedures. Ther Clin Risk Manag 2010;6:111-21.

2. Kaur M, Singh PM. Current role of dexmedetomidine in clinical anesthesia and intensive care. Anesth Essays Res 2011;5:128-33.

3. Philipp M, Brede M, Hein L. Physiological signifi cance of alpha(2)adrenergic receptor subtype diversity: one receptor is not enough. Am J Physiol Regul Integr Comp Physiol 2002;283:R287-95.

4. Lam SW, Alexander E, Sulsa GM. Drug Update: Dexmedetomidine Use in Critical Care; AACN Advanced Critical Care 2008;19:113-20.

5. Gertler R, Brown HC, Mitchell DH, Silvius E. Dexmedetomidine: a novel sedative-analgesic agent. Proc (Bayl Univ Med Cent) 2001;14:1321.

6. Candiotti KA, Bergese SD, Bokesch PM, Feldman MA, Wisemandle W, Bekker AY. Monitored Anesthesia Care with Dexmedetomidine: A Prospective, Randomized, Double-Blind, Multicenter Trial. Anesth Analg 2010;110:47-56.

7. Gupta R, Bogra J, Verma R, Kohli M, Kushwaha J, Kumar S. Dexmedetomidine as an intrathecal adjuvant for postoperative analgesia. Indian J Anaesth 2011;55:347-51.

8. Anand VG. Sedation in intensive care unit: Is Dexmedetomidine the best choice? Int J Crit Illn Inj Sci 2012;2:3-5.

9. Guo TZ, Buttermann AE, Jiang JY, Maze M. Dexmedetomidine injection into the locus ceruleus produces antinociception. Anesthesiology 1996;84:873-81.

10. Kaur M, Singh PM. Current role of dexmedetomidine in clinical anesthesia and intensive care. Anesth Essays Res 2011;5:128-33.

11. Grewal A. Dexmedetomidine: New avenues. J Anaesthesiol Clin Pharmacol 2011;27:297-302.

12. Karaman S, Evren V, Firat V, Cankayali I. Th e eff ects of dexmedetomidine on spontaneous contractions of isolated gravid rat myometrium. Adv Ther. 2006;23:238-43.

13. Tariq M, Cerny V, Elfaki I, Khan HA. Eff ects of subchronic versus acute in utero exposure to dexmedetomidine on fetal development in rats. Basic Clin Pharmacol Toxicol 2008;103:180-5.

14. Mishra N, Jain A, Sharma M. Intravenous dexmedetomidine for labour analgesia in women with preeclampsia. J. Evolution Med. Dent. Sci 2016;5(52):47-51

15. Palanisamy A, Klickovich RJ, Ramsay M, Ouyang DW, Tsen LC. Intravenous dexmedetomidine as an adjunct for labor analgesia and cesarean delivery anesthesia in a parturient with a tethered spinal cord. Int J Obs Anesth 2009;18:258-261.

16. Villa JMM. Dexmedetomidine as adjunct for analgesia in labor: a report of two cases. Rev Colomb Anestesiol. 2012;40(1):79-81

17. Abdalla W, Ammar MA, Tharwat AI. Combination of dexmedetomidine and remifentanil for labor analgesia: A doubleblinded, randomized, controlled study Saudi J Anaesth. 2015;9(4): 433438.

18. Sia AT, Sng BL. Intravenous dexmedetomidine for obstetric anaesthesia and analgesia: converting a challenge into an opportunity? Int J Obstet Anesth. 2009;18(3):204-6. 
Copyright: (C) the author(s), 2020. It is an open-access article distributed under the terms of the Creative Commons Attribution License (CC BY 4.0), which permits authors to retain ownership of the copyright for their content, and allow anyone to download, reuse, reprint, modify, distribute and/or copy the content as long as the original authors and source are cited.

How to cite this article: Jyothsna C, Kotha R. Role of Intravenous Dexmedetomidine as an Adjuvant in Labour Analgesia in Pre-eclampsia: A Prospective Study. Acad. Anesthesiol. Int. 2020;5(1):57-60.

DOI: dx.doi.org/10.21276/aan.2020.5.1.11 